ADVANCES IN

PSYCHIATRY \& NEUROLOGY

POSTEPY

Psychiatrii iNeurologii

Correspondence to/

Adres do korespondencji:

Anna Jasińska-Mikołajczyk

Adult Psychiatry Clinic

Karol Jonscher Clinical Hospital

of the Karol Marcinkowski University

of Medical Science in Poznań

27/33 Szpitalna St.

60-572 Poznań

phone: +48 618491400

e-mail: a.jasinska.mikolajczyk@gmail.com

Submitted/Otrzymano: 28.05.2017

Accepted/Przyjęto do druku: 02.10.2017

\section{ANTI-NMDA RECEPTOR ENCEPHALITIS IN A PATIENT WITH OVARIAN TERATOMA - CASE REPORT}

\author{
LIMBICZNE ZAPALENIE MÓZGU \\ Z PRZECIWCIAŁAMI PRZECIWKO \\ RECEPTOROM NMDA U PACJENTKI \\ Z GUZEM JAJNIKA - OPIS PRZYPADKU
}

\author{
Anna Jasińska-Mikołajczyk', Przemysław Osip², \\ Agnieszka Osip-Permoda ${ }^{1}$, Filip Rybakowski ${ }^{1}$
}

\begin{abstract}
'Adult Psychiatry Clinic, Karol Jonscher Clinical Hospital of the Karol Marcinkowsk University of Medical Science, Poznań, Poland

${ }^{2}$ Neurology Ward, the St. John Paul II HCP Medical Centre, Poznań, Poland

'Klinika Psychiatrii Dorosłych, Szpital Kliniczny im. Karola Jonschera, Uniwersytet Medyczny im. Karola Marcinkowskiego w Poznaniu, Polska

2Odział Neurologiczny, Centrum Medyczne HCP im. św. Jana Pawła II, Poznań, Polska
\end{abstract}

\begin{abstract}
Purpose: Limbic encephalitis is a clinical syndrome of various aetiologies: viral (the most often herpes simplex virus), associated with autoimmune diseases as well as a paraneoplastic syndrome (most commonly in the case of small cell lung carcinoma). This disease was first described by English neurologists and neuropathologists in 1960.

Case description: The case provided below shows a 46-year-old female suffering from autoimmune limbic encephalitis with antiNMDAR antibodies (anti-N-methyl-D-aspartate receptor antibodies) in the course of paraneoplastic syndrome, which was linked with ovarian tumour, i.e. teratocarcinoma mature (teratoma adultum ovaris). Considering previously unknown primary cancer, correct laboratory tests, imaging results and many psychopathological symptoms, the initial diagnosis was correlated with mental disorders. Soon, the symptoms of respiratory distress appeared in the deteriorating mental condition of the patient. Therefore, sedation and mechanical ventilation were necessary to implement.

Comment: Quick verification of diagnosis, active neurological and oncological examinations and causal treatment led to full recovery of the patient.
\end{abstract}

Key words: limbic encephalitis, anti-NMDAR antibodies, paraneoplastic syndrome.

\title{
Streszczenie
}

Cel: Limbiczne zapalenie mózgu to zespół objawów kliniczno-patologicznych o różnorodnej etiologii: wirusowej (najczęściej wirus opryszczki pospolitej), autoimmunologicznej, a także o charakterze zespołu paranowotworowego (najczęściej w przebiegu raka drobnokomórkowego płuc). Po raz pierwszy ta jednostka chorobowa została opisana przez angielskich neurologów i neuropatologów w $1960 \mathrm{r}$.

Opis przypadku: W pracy przedstawiono przypadek 46-letniej pacjentki z autoimmunologicznym limbicznym zapaleniem mózgu z przeciwciałami anty-NMDAR (anti-N-methyl-D-aspartate receptor) w przebiegu zespołu paranowotworowego, który był związany z guzem jajnika - potworniakiem dojrzałym (łac. teratoma adultum ovarii). Przy obecności nasilonych objawów psychiatrycznych oraz w większości prawidłowych wyników badań laboratoryjnych i obrazowych początkowo rozpoznanie wiązano z zaburzeniami psychicznymi. W krótkim czasie do pogarszającego się stanu psychicznego dołączyły objawy niewydolności oddechowej. Konieczne było zastosowanie sedacji i mechanicznej wentylacji chorej.

Komentarz: Szybka weryfikacja rozpoznania, aktywna diagnostyka neurologiczna i onkologiczna oraz wdrożenie leczenia przyczynowego pozwoliły na pełny powrót pacjentki do zdrowia.

Słowa kluczowe: limbiczne zapalenie mózgu, przeciwciała anty-NMDAR, zespół paranowotworowy. 
Anti-NMDA receptor encephalitis in a patient with ovarian teratoma - case report

Limbiczne zapalenie mózgu z przeciwciałami przeciwko receptorom NMDA u pacjentki z guzem jajnika-opis przypadku

\section{PURPOSE}

Limbic encephalitis (LE) most commonly occurs in patients of 60 years of age and affects both sexes to the same extent [1]. Generally, it can be divided into paraneoplastic limbic encephalitis (PLE) and non-paraneoplastic limbic encephalitis (NPLE). Typical clinical symptoms of this disease usually develop sub-acutely (acute development of the disease is rather rare) and include: short-term memory disturbance, behavioural and personality disorders (psychomotor agitation, aggression), auto- and allopsychic disorientation, affective disorders (emotional lability, depressive disorders), anxiety attacks, disturbed impulse and drive control, and sexual disinhibition. Patients also suffer from sleep disturbances, psychotic symptoms (especially hallucinations), neurological symptoms, such as paralysis or limb paresis, generalized and focal seizures, and autonomic nervous system dysfunctions (often leading to hypoventilation and respiratory failure requiring mechanical respiration). If limbic encephalitis involves the hypothalamus, such signs as hyperthermia, hyperthyroidism, and pituitary gland disorders may also occur [2].

While computed tomography (CT) scan is usually correct, abnormalities can be expected in magnetic resonance imaging (MRI) in the form of severely increased, unilateral or bilateral signal intensity in the medial temporal lobe in the T2-weighted images and FLAIR sequence [3].

In $80 \%$ of patients, the cerebrospinal fluid (CSF) tests show mild or moderate lymphocytic pleocytosis (usually less than 100 white blood cells/microliter), elevated protein levels (usually less than $150 \mathrm{mg} / \mathrm{dl}$ ), normal glucose levels and increased immunoglobulin index in the IgG class and the presence of oligoclonal bands [4]. It is also important to identify appropriate onconeural antibodies in the CSF test; it must, however, be borne in mind, that this is not always the case. In selected cases, positron emission tomography (PET) may show hypermetabolism in one or both temporal lobes [5], which often anticipates changes we may observe in MRI of the brain, and even the occurrence of clinical symptoms. Electroencephalography (EEG) usually describes abnormalities seen in patients between seizures (spikes and sharp waves) or slow waves present bilaterally or unilaterally in the temporal lobes [5].

In conclusion, the combination of typical clinical symptoms (Table 1) with changes in MRI and EEG (described above) should lead to the diagnosis of limbic encephalitis.

Paraneoplastic limbic encephalopathy (PLE) is an example of a paraneoplastic neurological syndrome, i.e. a group of diseases with a wide spectrum of clinical symptoms and immune responses (e.g. subacute cerebellar degeneration, opsoclonus myoclonus syndrome, sub-
CEL

Limbiczne zapalenie mózgu (limbic encephalitis - LE) występuje najczęściej ok. 60. roku życia i dotyka w takim samym stopniu obu płci [1]. Najogólniej można je podzielić na paranowotworowe zapalenie układu limbicznego (paraneoplastic limbic encephalitis - PLE) i nieparanowotworowe zapalenie układu limbicznego (non-paraneoplastic limbic encephalitis - NPLE). Diagnostyczne dla tej jednostki chorobowej są objawy kliniczne o podostrym, rzadziej ostrym początku, takie jak: zaburzenia pamięci świeżej, zaburzenia zachowania (pobudzenie psychoruchowe, napady agresji), zaburzenia orientacji auto- lub allopsychicznej, zaburzenia afektywne (labilność emocjonalna, zaburzenia depresyjne), napady lęku, zaburzenia kontroli popędów, odhamowanie. U pacjentów obserwuje się również zaburzenia snu, objawy psychotyczne (zwłaszcza omamy), objawy neurologiczne: porażenia lub niedowłady kończyn, częściowo złożone oraz uogólnione napady padaczkowe, a także zaburzone funkcjonowanie układu autonomicznego (prowadzące często do hipowentylacji i niewydolności oddechowej wymagającej mechanicznego wspomagania oddechu). W przypadku objęcia procesem chorobowym podwzgórza mogą wystąpić hipertermia, żarłoczność i zaburzenia wydzielania hormonów przez przysadkę mózgową [2].

O ile obraz tomografii komputerowej jest najczęściej prawidłowy, o tyle w obrazie rezonansu magnetycznego można spodziewać się nieprawidłowości w postaci patologicznego wzrostu intensywności sygnału w przyśrodkowej części płata skroniowego jedno- lub obustronnie w obrazach T2-zależnych i w sekwencji FLAIR [3].

U 80\% pacjentów w badaniu płynu mózgowego (PMR) wykazuje się łagodną lub umiarkowaną pleocytozę limfocy-

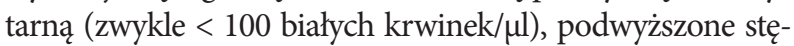
żenie białka (zwykle < $150 \mathrm{mg} / \mathrm{dl}$ ), prawidłowe stężenie glukozy i często podwyższony indeks immunoglobulin w klasie IgG oraz obecność prą̨żów oligoklonalnych [4]. Istotne jest również zidentyfikowanie w PMR odpowiednich przeciwciał onkoneuronalnych, jednak należy pamiętać, że nie zawsze się to udaje. W wybranych przypadkach wykonanie badania PET może wykazać hipermetabolizm w jednym lub obu płatach skroniowych [5], co często wyprzedza zmiany, jakie możemy zaobserwować w badaniu MRI mózgowia, a nawet wystąpienie objawów klinicznych. W EEG zazwyczaj opisuje się zmiany napadowe (iglice i fale ostre) lub fale wolne jednolub obustronnie w okolicach skroniowych mózgu [5].

Podsumowując, możemy stwierdzić, że połączenie typowych objawów klinicznych (tab. 1) ze zmianami w obrazie rezonansu magnetycznego i EEG (opisane powyżej) powinny skłaniać do rozważenia diagnozy LE.

Paranowotworowe limbiczne zapalenie mózgu (PLE) jest przykładem paraneoplastycznego zespołu neurologicznego - grupy chorób o szerokim spektrum objawów klinicznych i zależności immunologicznych (jak np. podostre zwyrodnienie móżdżku, zespół opsoklonie/mioklonie, 
Table 1. Clinical symptoms that may suggest limbic encephalitis

Tabela 1. Kliniczne objawy mogące wskazywać na rozpoznanie zapalenia układu limbicznego

\begin{tabular}{|c|c|}
\hline Type of symptoms/Grupa objawów & Symptoms/Objawy \\
\hline Prodromal symptoms/Objawy prodromalne & $\begin{array}{l}\text { - Slight increase in body temperature/Nieznaczny wzrost temperatury ciała } \\
\text { - General exhaustion/Ogólne osłabienie } \\
\text { - Myalgia/Bóle mieśniowe } \\
\text { - Headaches/Bóle głowy } \\
\text { - Upper respiratory tract infection/Objawy infekcji górnych dróg oddechowych }\end{array}$ \\
\hline Psychiatric symptoms/Objawy psychiatryczne & $\begin{array}{l}\text { - Psychomotor agitation/Pobudzenie psychoruchowe } \\
\text { - Aggressive behaviour/Zachowania agresywne } \\
\text { - Disturbed impulse and drive control (including sexual disinhibition)/Zaburzona } \\
\text { - Affrectivimpulsów i popędów (m.in. odhamowanie w sferze seksualnej) } \\
\text { afektywne (labilność emocjonalionalility, depressive disorders)/Zaburzenia } \\
\text { - Anxiety disorders/Zaburzenia lękowe } \\
\text { - Psychotic symptoms (visual and auditory hallucinations, delusions)/Objawy } \\
\text { psychotyczne (halucynacje wzrokowe i słuchowe, urojenia) }\end{array}$ \\
\hline Cognitive disorders/Zaburzenia poznawcze & $\begin{array}{l}\text { - Problems with episodic memory/Problemy z pamięcia epizodyczna } \\
\text { - Attention and concentration deficit/Zaburzenia uwagi i koncentracji } \\
\text { - Auto- and allopsychic disorientation/Zaburzenia orientacji auto- } \\
\text { i allopsychicznej }\end{array}$ \\
\hline Neurological symptoms/Objawy neurologiczne & $\begin{array}{l}\text { - Headaches/Bóle głowy } \\
\text { - Epileptic seizures/Napady padaczkowe } \\
\text { - Dyskinesia (especially the mouth)/Dyskinezy (zwłaszcza dotyczące ust) } \\
\text { - Paralysis or limb paresis/Porażenia lub niedowłady kończyn } \\
\text { - Cerebellar ataxia/Ataksja móżdżkowa } \\
\text { - Catatonia/Katatonia }\end{array}$ \\
\hline General symptoms/Objawy ogólne & $\begin{array}{l}\text { - Instability of the autonomous system/Niestabilność układu autonomicznego } \\
\text { - Fluctuating blood pressure/Wahania ciśnienia tętniczego } \\
\text { - Hypoventilation/Hipowentylacja } \\
\text { - Loss of consciousness/Utrata przytomności }\end{array}$ \\
\hline
\end{tabular}

acute sensory neuropathy, Lambert-Eaton myasthenic syndrome and dermatomyositis) that occur as complications of cancerous diseases but are not caused by either local effects of cancer or nervous system metastases. Cancers most commonly associated with PLE include: small cell lung cancer (40\%), testicular embryonal carcinoma (20\%), breast cancer (8\%), Hodgkin's lymphoma, thymoma and immature teratoma [6]. Neurological symptoms or psychiatric disorders can anticipate oncological diagnosis in over $60 \%$ of patients. Sometimes it takes several months or years (with an average of 3.5 months) to diagnose cancerous disease from the moment the first abnormalities are observed [6].

At the end of the $20^{\text {th }}$ century, the presence of onconeural antibodies was discovered in serum of patients suffering from such disorders as those described above (onconeural antibodies show cross-reactivity with tumour cells and nervous system cells) [7-10].

So far, many onconeural antibodies have been identified. Since 2004, these antibodies have been classified as 'well-characterized' and 'poorly characterized'. The former antibodies include: anti-Hu, Yo, Ri, Ma1, Ma2/Ta, CV2/CRMP5 and anti-amphiphysin antibodies [11]. Detection of these antibodies in serum or cerebrospinal fluid makes it possible for doctors to diagnose paraneoplastic syndrome because their specificity is 95-100\%. The first onconeural antibodies were called podostra neuropatia czuciowa, zespół miasteniczny Lamberta-Eatona oraz zapalenie skórno-mięśniowe), które występują jako powikłania choroby nowotworowej, lecz nie są spowodowane miejscowym działaniem nowotworu ani przerzutami do układu nerwowego. Nowotwory, które są najczęściej z nim powiązane, to: drobnokomórkowy rak płuc (40\%), zarodkowe nowotwory jąder (20\%), rak sutka (8\%), ziarnica złośliwa, grasiczak i potworniak niedojrzały [6]. Objawy neurologiczne lub zaburzenia psychiatryczne mogą wyprzedzać rozpoznanie onkologiczne u ponad $60 \%$ chorych. Od chwili zaobserwowania pierwszych nieprawidłowości do zdiagnozowania choroby nowotworowej mija czasami kilka miesięcy lub lat, średnio 3,5 miesiąca [6].

Pod koniec XX w. w surowicy krwi chorych przejawiających opisane powyżej zaburzenia odkryto przeciwciała onkoneuronalne (przeciwciała wykazujące reakcję krzyżową z komórkami guza i komórkami układu nerwowego) [7-10].

Do dzisiaj zidentyfikowano wiele przeciwciał onkoneuronalnych. Od 2004 r. przeciwciała te dzieli się na dobrze i słabo scharakteryzowane. Do tych pierwszych zalicza się przeciwciała anty-Hu, Yo, Ri, Ma1, Ma2/Ta, CV2/CRMP5 i przeciwciała przeciw amfifizynie [11]. Wykrycie w surowicy lub płynie mózgowo-rdzeniowym tych przeciwciał umożliwia ustalenie pewnego rozpoznania zespołu paranowotworowego, gdyż ich swoistość wynosi 95-100\%. Pierwsze przeciwciała onkoneuronalne oznaczano pierwszymi 
Anti-NMDA receptor encephalitis in a patient with ovarian teratoma - case report

Limbiczne zapalenie mózgu z przeciwciałami przeciwko receptorom NMDA u pacjentki z guzem jajnika-opis przypadku

Table 2. The presence of onconeural antibodies and cancers causing their formation Tabela 2. Obecność przeciwciał onkoneuronalnych i generujące ich powstanie nowotwory

\begin{tabular}{|c|c|}
\hline Onconeural antibodies/Przeciwciała onkoneuronalne & Cancers/Nowotwory \\
\hline Anti-Hu/anty-Hu (ANNA-1, anti-neuronal nuclear antibody 1) & $\begin{array}{l}\text { - Small cell lung cancer/Drobnokomórkowy rak płuc } \\
\text { - Non-small cell lung cancer/Niedrobnokomórkowy rak } \\
\text { płuc } \\
\text { - Neuroblastoma/Nerwiak zarodkowy } \\
\text { - Prostate cancer/Rak gruczołu krokowego } \\
\text { - Seminoma/Nasieniak }\end{array}$ \\
\hline Anti-Yo/anty-Yo (PCA-1, anti-Purkinje cell antibody 1) & $\begin{array}{l}\text { - Ovarian cancer/Rak jajnika } \\
\text { - Breast cancer/Rak sutka }\end{array}$ \\
\hline Anti-CV2/anty-CV2 (anti-CRMP5, collapsin response-mediated protein 5) & $\begin{array}{l}\text { - Small cell lung cancer/Drobnokomórkowy rak płuc } \\
\text { - Thymoma/Grasiczak } \\
\text { - Uterine sarcoma/Mięsak macicy }\end{array}$ \\
\hline Anti-Ri/anty-Ri (ANNA-2, anti-neuronal nuclear antibody 2) & $\begin{array}{l}\text { - Breast cancer/Rak piersi } \\
\text { - Small cell lung cancer/Drobnokomórkowy rak płuc }\end{array}$ \\
\hline $\begin{array}{l}\text { Anti-Ma/anti-Ta/anty-Ma/anty-Ta (Ma2/Ta weighing 41,5 kDa or Mal - } 40 \text { kDa)/ } \\
\text { (Ma2/Ta o masie 41,5 kDa lub Ma } 1 \text { - } 40 \text { kDa) }\end{array}$ & - Testicular cancer/Rak jąder \\
\hline $\begin{array}{l}\text { Anti-CV2/anty-CV2 (anti-CRMP5, collapsin response-mediated } \\
\text { protein 5) }\end{array}$ & $\begin{array}{l}\text { - Small cell lung cancer/Drobnokomórkowy rak płuc } \\
\text { - Thymoma/Grasiczak } \\
\text { - Uterine sarcoma/Mięsak macicy }\end{array}$ \\
\hline $\begin{array}{l}\text { Anti-amphiphysin ( } 128 \text { kDa protein in synaptic vesicles)/ } \\
\text { Anty-amfifizyna (białko } 128 \text { kDa w pęcherzykach synaptycznych) }\end{array}$ & $\begin{array}{l}\text { - Small cell lung cancer/Drobnokomórkowy rak płuc } \\
\text { - Ovarian cancer/Rak jajnika }\end{array}$ \\
\hline
\end{tabular}

using the first two letters of the first patient's name. At present, their naming is based on antigens they are targeting. Table 2 shows well-characterized onconeural antibodies and the most common cancers causing their formation.

Limbic encephalitis should be differentiated from many disease units, often with a very similar clinical course, such as herpes simplex encephalopathy, Hashimoto encephalopathy, toxic and metabolic encephalopathies, central nervous system (CNS) metastases, primary CNS lymphoma, psychotic symptoms in affective diseases or schizophrenia.

Suspicion or diagnosis of limbic encephalitis obliges doctors to actively seek for a tumour. Diagnosis should be planned individually for each patient, but there are general recommendations submitted by Bien and Egler [12] who suggest the following tests: contrast-enhanced computed tomography of thoracic and abdominal organs in all patients, gynaecological examination and mammography in women and urological examination in men (for testicular cancer in men under 50 years of age and for prostate cancer in men who are over 50) and test for prostate specific antigen (PSA). When in doubt, it is recommended to use the fluorodeoxyglucose positron emission tomography.

The primary task after the patient is diagnosed with PLE is to treat the underlying disease, most likely tumour removal. This can provide the patient with a chance of neurological stabilization and help him/her restore balance. Considering immunological aetiology of the disease, steroid medications, intravenous immunoglobulins, and plasmapheresis therapy are used for symptomatic dwiema literami nazwiska pierwszego chorego. Obecnie ich nazewnictwo opiera się na antygenach, przeciwko którym sa skierowane. W tabeli 2 przedstawiono dobrze scharakteryzowane przeciwciała onkoneuronalne i najczęstsze nowotwory przyczyniające się do ich powstania.

Limbiczne zapalenie mózgu należy różnicować $\mathrm{z}$ wieloma jednostkami, często o bardzo podobnym przebiegu klinicznym, m.in. z opryszczkowym zapaleniem mózgu, encefalopatią Hashimoto, encefalopatiami toksycznymi i metabolicznymi, przerzutami do ośrodkowego układu nerwowego (OUN), pierwotnym nowotworem OUN, objawami psychotycznymi w przebiegu chorób afektywnych bądź schizofrenii.

Podejrzenie lub rozpoznanie LE zobowiązuje do aktywnego poszukiwania guza. Diagnostyka powinna być planowana indywidualnie dla każdego pacjenta, istnieją jednak ogólne rekomendacje przedstawione przez Bien i Egler [12], które proponują wykonanie tomografii komputerowej klatki piersiowej i jamy brzusznej ze wzmocnieniem kontrastowym u wszystkich chorych oraz badania ginekologicznego i mammografii u kobiet, a u mężczyzn poniżej 50. roku życia badania urologicznego pod kątem guza jąder, natomiast po 50. roku życia badania urologicznego pod kątem raka prostaty i oznaczenie poziomu PSA. W wątpliwych przypadkach zaleca się wykonanie PET z użyciem fluorodeoksyglukozy.

Podstawowym zadaniem, po wykryciu u pacjenta PLE, jest leczenie choroby podstawowej - najczęściej usunięcie guza. Może to zapewnić choremu szansę na stabilizację neurologiczną i wyrównanie stanu psychicznego. Uwzględniając immunologiczną etiologię choroby, w leczeniu objawowym stosuje się leki steroidowe, wlewy dożylne immunoglobulin oraz zabiegi plazmaferezy. 
treatment. If the above-mentioned treatment turns out to be ineffective, immunosuppressive therapy with cyclophosphamide or rituximab is suggested [13]. Benzodiazepines are recommended to control psychomotor agitation or to stop epileptic seizures.

\section{CASE DESCRIPTION}

The first symptoms and signs of the disease occurred in the patient when she was 46 years old. The patient did not receive psychiatric or neurological treatment before. There is no family history of mental illness and disorders. The patient is an agriculture technician by education; she was a blue-collar worker in a meat processing plant. According to the interview, she had repeated respiratory tract infections but besides them, no significant burden of somatic symptoms was seen. In March 2015, 4 months after the patient gave birth to her second son (the pregnancy was terminated in the $7^{\text {th }}$ month following placental abruption), the patient suffered rapid deterioration of mood, general weakness, muscle pain, headaches and dizziness, double vision, progressive speech disorders (probably mixed-type aphasia). In addition, there were behavioural and emotional disorders: the patient did not want to get up of bed; she was afraid to leave the house, avoided contact with other people and was aggressive. She does not remember what happened to her later. Based on the family account and medical records, initially she was admitted to an internal medicine ward, from where, after excluding significant deviations based on CT scan of the head and once basic laboratory tests were taken, she was moved to a neurology ward. After admission to the neurology ward, the patient behaved in a cheerful or weeping manner; she was agitated, aggressive, sometimes showed sexual disinhibition. Aphasia-like speech disorders were also reported (logopaedic examination revealed schizophasia-like speech disorders, lack of verbal activity, numerous neologisms). The MRI scan (T2 and FLAIR images) showed single hyperintense loci (ischaemic lesion), $3 \mathrm{~mm}$ in diameter, in the semi-oval centre; however, bedsides the lesion, the MRI of the brain was normal. No significant deviations were found in cerebrospinal fluid and laboratory tests. In view of the above, it was decided to take the patient to a psychiatric ward with suspicion of a depressive episode. There was no verbal communication with the patient. She did not respond to requests and orders, either.

During hospitalization, she had a massive upper respiratory tract infection. As general condition of the patient continued to deteriorate and respiratory failure kept developing, the patient was referred to the Intensive Care Unit, where the decision was made to implement sedation and mechanical ventilation. Once the patient's somatic condition was stabilized, she was repeatedly consulted with a neurologist, a video EEG test was per-
W przypadku braku skuteczności ww. leczenia wskazana jest terapia immunosupresyjna $\mathrm{z}$ zastosowaniem cyklofosfamidu lub rytuksymabu [13]. W celu opanowania pobudzenia psychoruchowego lub przerywania napadów padaczkowych polecane są benzodiazepiny.

\section{OPIS PRZYPADKU}

Pierwsze objawy choroby pojawiły się u pacjentki w wieku 46 lat. Do tego czasu nie była leczona ani psychiatrycznie, ani neurologicznie. Wywiad rodzinny pod względem chorób i zaburzeń psychicznych nieobciążony. $\mathrm{Z}$ wykształcenia technik rolnictwa, pracowała fizycznie w masarni. W wywiadzie częste infekcje dróg oddechowych, poza tym bez istotnych obciążeń chorobami somatycznymi. W marcu 2015 r., 4 miesiące po porodzie drugiego syna (ciąża rozwiązana w 7. miesiącu z powodu przedwczesnego oddzielenia się łożyska), u pacjentki nastąpiło gwałtowne pogorszenie samopoczucia. Skarżyła się na ogólne osłabienie, bóle mięśniowe, bóle i zawroty głowy, podwójne widzenie, postępujące zaburzenia mowy (prawdopodobnie o charakterze afazji mieszanej). Ponadto pojawily się zaburzenia zachowania i emocji: pacjentka nie chciała wstawać z łóżka, bała się wychodzić z domu, unikała kontaktów z ludźmi, bywała agresywna. Kobieta nie pamięta, co działo się z nią $\mathrm{w}$ późniejszym okresie. $Z$ relacji rodziny oraz dokumentacji medycznej wiadomo, że początkowo trafiła ona na oddział chorób wewnętrznych, skąd, po wykluczeniu istotnych odchyleń w TK głowy oraz podstawowych badaniach laboratoryjnych, została przewieziona na oddział neurologiczny. Przy przyjęciu na oddział neurologiczny pacjentka zachowywała się w sposób wesołkowaty bądź płaczliwy, była pobudzona, agresywna, chwilami przejawiała odhamowanie seksualne. Zaobserwowano również zaburzenia mowy przypominające afazję ( $w$ badaniu logopedycznym stwierdzono zaburzenia mowy o charakterze schizofazji, brak aktywności słownej, liczne neologizmy). W wykonanym badaniu MRI zobrazowano w lewym centrum semiovale pojedyncze ognisko hiperintensywne w obrazach T2 i FLAIR o średnicy $3 \mathrm{~mm}$ i charakterze zmiany niedokrwiennej, poza tym obraz MR mózgowia był prawidłowy. W PMR oraz badaniach laboratoryjnych nie stwierdzono istotnych odchyleń. Wobec powyższych zadecydowano o przekazaniu pacjentki na oddział psychiatryczny z podejrzeniem epizodu depresji. Pacjentka nie nawiązywała kontaktu słownego, nie reagowała na prośby i polecenia.

W trakcie hospitalizacji u chorej wystąpiła masywna infekcja górnych dróg oddechowych. Ze względu na pogarszający się stan ogólny pacjentki oraz rozwijającą się niewydolność oddechową chora została przekazana na Oddział Intensywnej Terapii (OIT), gdzie podjęto decyzję o zastosowaniu sedacji i mechanicznej wentylacji. Po ustabilizowaniu stanu somatycznego chorą wielokrotnie konsultowano neurologicznie, wykonano badania EEG 
Anti-NMDA receptor encephalitis in a patient with ovarian teratoma - case report

Limbiczne zapalenie mózgu z przeciwciałami przeciwko receptorom NMDA u pacjentki z guzem jajnika-opis przypadku

Table 3. Result of indirect immunofluorescence assay to detect antibodies, April 2015

Tabela 3. Wynik badania przeciwciał metodą immunofluorescencji pośredniej, kwiecień $2015 \mathrm{r}$.

\begin{tabular}{|l|c|}
\hline Antibodies/Przeciwciała & Score/Wynik \\
\hline Anti-AMPA 1/anty-AMPA 1 & Absent/Nieobecne \\
\hline Anti-CASPR 2/anty-CASPR 2 & Absent/Nieobecne \\
\hline Anti-NMDA/anty-NMDA & Present/Obecne \\
\hline Anti-GABAR B1/anty-GABAR B1 & Absent/Nieobecne \\
\hline Anti-AMPA 2/anty-AMPA 2 & Absent/Nieobecne \\
\hline Anti-LGI 1/anty-LGI 1 & Absent/Nieobecne \\
\hline
\end{tabular}

Table 4. Results of onconeuronal and anti-neural antibody testing - indirect immunofluorescence, June 2015

Tabela 4. Wynik badania przeciwciał onkoneuronalnych i antyneuralnych immunofluorescencja pośrednia, czerwiec $2015 \mathrm{r}$.

\begin{tabular}{|l|l|}
\hline Antibodies/Przeciwciała & Score/Wynik \\
\hline Anti-Hu/anty-Hu & Absent/Nieobecne \\
\hline Anti-Ri/anty-Ri & Absent/Nieobecne \\
\hline Anti-Yo/anty-Yo & Absent/Nieobecne \\
\hline Anti-amphiphysin/przeciw amfifizynie & Absent/Nieobecne \\
\hline Anti-CV2/anty-CV2 & Absent/Nieobecne \\
\hline Anti-Ma/Ta/anty-Ma/Ta & Absent/Nieobecne \\
\hline Anti-Tr/anty-Tr & Absent/Nieobecne \\
\hline Anti-GAD/anty-GAD & Absent/Nieobecne \\
\hline Anti-MAG/anty-MAG & Absent/Nieobecne \\
\hline Anti-myelin/przeciw mielinie & Absent/Nieobecne \\
\hline Anti-unmyelinated fibres/przeciw włóknom bezrdzennym & Absent/Nieobecne \\
\hline Anti-neuroendothelium/przeciw neuroendotelium & Absent/Nieobecne \\
\hline
\end{tabular}

formed (frontal-central-temporal electrodes with left side predominance recorded almost continuous delta wave activity of $1.5-3-\mathrm{Hz}$ frequency with an amplitude of up to $115 \mu \mathrm{V}$ propagating to the adjacent hemisphere, which stopped after diazepam was administered to the patient), a convulsive status epilepticus was confirmed, and the presence of anti-NMDA antibodies in serum was found (April 2015). All these signs led to the final diagnosis of autoimmune limbic encephalitis.

During further diagnostic investigation, a test of expanded panel of onconeuronal and anti-neuronal antibodies in serum was also performed.

Steroid therapy (methylprednisolone, $1 \mathrm{~g}$ given as an intravenous injection for 5 days) was used in the treatment in addition to immunoglobulins (Octagam Immunoglobulinum humanum normale; total dose: $2 \mathrm{~g} / \mathrm{kg}$ of body weight) and antiepileptic drugs (diazepam, phenytoin, valproic acid, levetiracetam) followed by 7 plasmapheresis treatments; the therapy continued in the neurology ward using prednisone (doses were gradually
(wideo-EEG: w odprowadzeniach czołowo-centralno-skroniowych $\mathrm{z}$ przewagą strony lewej zarejestrowano prawie ciągłą czynność fal delta $1,5-3 \mathrm{~Hz}$ o amplitudzie do $115 \mu \mathrm{V}$ propagującą do okolic sąsiednich półkuli przeciwnej, która ustąpiła po podaniu diazepamu), potwierdzono drgawkowy stan padaczkowy, wykryto obecność przeciwciał anty-NMDA w surowicy krwi (kwiecień 2015 r.), co pozwoliło na ustalenie ostatecznego rozpoznania autoimmunologicznego zapalenia układu limbicznego.

W trakcie późniejszej diagnostyki wykonano również badanie rozszerzonego panelu przeciwciał onkoneuronalnych oraz antyneuronalnych w surowicy krwi.

W leczeniu zastosowano steroidoterapię (metyloprednizon - $1 \mathrm{~g}$ dożylnie przez $5 \mathrm{dni}$ ), podano immunoglobuliny (Octagam - Immunoglobulinum humanum normale dawka całkowita: 2 g/kg m.c.) oraz leki przeciwpadaczkowe (diazepam, fenytoina, kwas walproinowy, lewetyracetam), następnie przeprowadzono 7 zabiegów plazmaferezy. Leczenie kontynuowano na oddziale neurologicznym, podając prednizon (dawki stopniowo redukowano). Uzyskano 
reduced). Neurological stabilization was achieved (MayJune 2016), the patient re-established verbal communication, followed simple commands, regained full auto- and allopsychic orientation. Thanks to further multifaceted rehabilitation, the patient now has no significant neurological deficits and psychiatric disorders. She does not remember the disease period at all. Baseline MRI showed slightly enlarged subarachnoid space; minor irregular hyperintense foci (most likely chronic ischaemic lesions) were found in the PD, T2 and FLAIR images of both frontal and medial thalamus, but they showed no pathological enhancement following the administration of intravenous contrast material. No extreme changes were found in the brain.

The patient is kept under constant supervision of a neurologist. She does not require psychiatric treatment.

As early as in the initial period of hospitalization, having regard to frequent occurrence of limbic encephalitis as a paraneoplastic syndrome, further diagnostic investigation was conducted to locate potential cancer site. The abdomen/pelvis CT scan showed right ovary cyst $25 \mathrm{~mm}$ in diameter, which was reported to cause the paraneoplastic syndrome. Histopathological examination of the removed ovary (in October 2016, 7 months from the beginning of the cancer) showed teratoma adultum cysticum ovarii (ovarian teratoma). After the surgery, considering the diagnosis, the patient did not require any further oncological treatment.

\section{COMMENT}

Anti-NMDA receptor limbic encephalitis was first described as a paraneoplastic syndrome in 2007, in a patient with cognitive and behavioural disorders in the course of an ovarian teratoma [14]. Most patients with this condition have typical psychiatric and neurological symptoms, such as cognitive disorders, affective disorders, psychotic syndromes (hallucinogenic), psychomotor agitation, sexual disinhibition, seizures (focal or generalized), paralysis and limb paresis. The clinical progression of limbic encephalitis usually begins with prodromal symptoms, including headaches, flu-like illness followed by psychiatric and neurological disorders, and - later on - symptoms similar to an upper respiratory infection. Once the patient is fairly stable, s/he typically goes through periods of psychomotor hyperactivity [15]. Certain diagnosis can be made after detecting anti-NMDA antibodies in serum and/or in CSF.

NMDA receptor antibody encephalitis is often diagnosed in children and young adults, predominantly females. In cohort studies of over 500 cases, a tumour was found in $38 \%$ of patients, $94 \%$ of which accounted for ovarian teratoma and $2 \%$ - for extragonadal teratoma [16]. In the clinical group of about 400 patients with stabilizację stanu neurologicznego (maj-czerwiec 2016 r.), chora nawiązała kontakt słowny, wykonywała proste polecenia, odzyskała pełną orientację auto- i allopsychiczną. W wyniku dalszej wielopłaszczyznowej rehabilitacji funkcjonuje obecnie bez istotnych deficytów neurologicznych oraz zaburzeń psychiatrycznych. Okres zachorowania pokryty jest u pacjentki niemal całkowitą niepamięcią. W kontrolnym badaniu MRI uwidoczniono nieznacznie poszerzone przestrzenie podpajęczynówkowe, w obrazach PD, T2 i FLAIR w przednich i przyśrodkowych częściach obu wzgórz zobrazowano drobne, nieregularne ogniska hiperintensywne, które nie wykazywały patologicznych wzmocnień po dożylnym podaniu środka kontrastowego (prawdopodobnie były to zmiany niedokrwienne), poza tym w obrębie mózgowia nie znaleziono zmian patologicznych.

Pacjentka znajduje się pod ciągłą opieką poradni neurologicznej. Nie wymaga leczenia psychiatrycznego.

Już $\mathrm{w}$ początkowym okresie hospitalizacji, mając na uwadze częste występowanie zapalenia układu limbicznego jako zespołu paranowotworowego, rozpoczęto aktywną diagnostykę w celu zlokalizowania potencjalnego ogniska nowotworowego. W TK jamy brzusznej i miednicy opisano w rzucie prawego jajnika torbiel o średnicy $25 \mathrm{~mm}$. Guz ten był prawdopodobnie czynnikiem sprawczym wystąpienia zespołu paraneoplastycznego. Badanie histopatologiczne usuniętego w trybie planowym jajnika (październik 2016 r., 7 miesięcy od początku choroby) wykazało teratoma adultum cysticum ovarii (potworniak dojrzały jajnika). Po operacji, zważywszy na ustalone rozpoznanie, pacjentka nie wymagała dalszego leczenia onkologicznego.

\section{KOMENTARZ}

Limbiczne zapalenie mózgu z obecnymi przeciwciałami anty-NMDAR jako zespół paraneoplastyczny zostało opisane po raz pierwszy w $2007 \mathrm{r}$. u pacjentki z zaburzeniami poznawczymi i zachowania w przebiegu potworniaka jajnika [14]. Większość pacjentów z tym schorzeniem przejawia typowe objawy psychiatryczne i neurologiczne: zaburzenia poznawcze, afektywne, objawy psychotyczne (halucynacje), pobudzenie psychoruchowe, odhamowanie seksualne, a także napady padaczkowe (częściowe lub uogólnione) oraz niedowłady i porażenia kończyn. Progresja kliniczna LE zaczyna się zazwyczaj od objawów przypominających przeziębienie, następnie pojawiają się zaburzenia psychiatryczne i neurologiczne, w dalszej kolejności dość często obserwuje się cechy niewydolności oddechowej, a po stabilizacji stanu ogólnego - okresy nadpobudliwości psychoruchowej [15]. Pewne rozpoznanie można ustalić po wykryciu przeciwciał anty-NMDA w surowicy i/lub PMR.

Limbiczne zapalenie mózgu z przeciwciałami anty-NMDAR jest często diagnozowane u dzieci i młodych dorosłych, przeważa płeć żeńska. W badaniach kohortowych obejmujących ponad 500 przypadków u 38\% pacjentów wykryto guza, z czego u $94 \%$ był to potworniak 
diagnosed limbic encephalitis, only $2 \%$ had a tumour other than ovarian teratoma [17]. Currently, this type of tumour is the only one so strongly associated with anti-NMDA receptor encephalitis.

Considering the above-mentioned case and more and more numerous reports of increasing prevalence of limbic encephalitis, it is worth taking note of this disease unit in the differential diagnosis of certain psychiatric and neurological disorders. Special vigilance should be evinced when subacute or acute cognitive disorders and some psychiatric disorders begin to develop in addition to the occurrence of lobe epilepsy in adult life [18], although young age is not an exclusion criterion. If PLE is suspected or diagnosed, one of the main tasks is to expand diagnostic investigation to target potential cancer because successful detection and treatment of the underlying neoplasm is critical and carries the best chance of patient clinical stabilization. jajnika, u 2\% potworniak okolicy pozagonadalnej [16]. W grupie klinicznej obejmującej ok. 400 osób ze zdiagnozowanym zapaleniem układu limbicznego tylko u $2 \%$ wykryto guza innego niż potworniak jajnika [17]. Nowotwór ten jest obecnie jedynym tak silnie związanym z LE z przeciwciałami anty-NMDAR.

Zważywszy na zaprezentowany powyżej przypadek i coraz liczniejsze doniesienia o nowych zachorowaniach na zapalenie układu limbicznego, warto zwrócić uwagę na tę jednostkę chorobową $\mathrm{w}$ diagnostyce różnicowej niektórych zaburzeń psychiatrycznych i neurologicznych. Szczególną czujność powinien budzić podostry lub ostry początek zaburzeń poznawczych i niektórych zaburzeń psychiatrycznych oraz pojawienie się napadów padaczkowych skroniowych w wieku dorosłym [18], mimo że młody wiek nie jest kryterium wykluczającym. W przypadku podejrzenia lub rozpoznania PLE jednym z podstawowych zadań staje się poszerzenie diagnostyki o ukierunkowaną na poszukiwanie potencjalnego nowotworu, gdyż to właśnie jego leczenie stwarza największą szansę na stabilizację kliniczną pacjenta.

\section{Conflict of interest/Konflikt interesu}

Absent./Nie występuje.

Financial support/Finansowanie

Absent./Nie występuje.

\section{References/Piśmiennicłwo}

1. Gołąb-Jankowska M, Nowacki P. Limbiczne zapalenie mózgu - przegląd piśmiennictwa. Roczniki Pomorskiej Akademii Medycznej w Szczecinie 2011; 57: 5-11.

2. Dalmau J, Rosenfeld M. Paraneoplastic syndromes of the CNS. Lancet Neurol 2008; 7: 327-340.

3. Tuzun E, Dalmau J. Limbic encephalitis and variants: classification, diagnosis and treatment. Neurologist 2007; 13: 261-271.

4. Basu S, Alavi A. Role of FDG-PET in the clinical management of paraneoplastic neurological syndrome: detection of the underlying malignancy and the brain PET-MRI correlates. Mol Imaging Biol 2008; 10: 131-137.

5. Barry H, Byrne S, Barrett E, Murphy KC, Cotter DR. Anti-N-methyl-d-aspartate receptor encephalitis: Review of clinical presentation, diagnosis and treatment. BJ Psych Bull 2015; 39: 19-23.

6. Gultekin SH, Rosenfeld MR, Voltz R, Eichen J, Posner JB, Dalmau J. Paraneoplastic limbic encephalitis: neurological symptoms, immunological findings and tumour association in 50 patients. Brain 2000; 123: 1481-1494.

7. Graus F, Elkon KB, Cordon-Cardo C, Posner JB. Sensory neuronopathy and small cell lung cancer. Antineuronal antibody that also reacts with the tumour. Am J Med 1986; 80: 45-52.

8. Anderson NE, Rosenblum MK, Graus F, Wiley RG, Posner JB. Autoantibodies in paraneoplastic syndromes associated with small - cell lung cancer. Neurology 1988; 38: 1391-1398.

9. Dalmau J, Furneaux HM, Rosenblum MK, Graus F, Posner JB. Detection of the anti Hu antibody in specific regions of the nervous system and tumour from patients with paraneoplastic encephalomyelitis/sensory neuronopathy. Neurology 1991; 41: 1757-1764.

10. Zuliani L, Saiz A, Tavolato B, Giometto B, Vincent A, Graus F. Paraneoplastic limbic encephalitis associated with potassium channel antibodies: value of anti-glial nuclear antibodies in identifying the tumour. J Neurol Neurosurg Psychiatry 2007; 78: 204-205.

11. Michalak S, Kozubski W. Neurologiczne zespoły paranowotworowe. Pol Przegl Neurol 2008; 4: 26-31.

12. Bien CG, Elger CE. Limbic encephalitis: a cause of temporal lobe epilepsy with onset in adult life. Epilepsy Behav 2007; 10: 529-538. 
13. Shams'ili S, de Beukelaar J, Gratama JW, et al. An uncontrolled trial of rituximab for antibody associated paraneoplastic neurological syndromes. J Neurol 2006; 253: 16-20.

14. Dalmau J, Tüzün E, Wu HY, et al. Paraneoplastic anti-N-methyl-D-aspartate receptor encephalitis associated with ovarian teratoma. Ann Neurol 2007; 61: 25-36.

15. Iizuka T, Sakai F, Ide T, et al. Anti-NMDA receptor encephalitis in Japan: Long-term outcome without tumor removal. Neurology 2008; 70: 504-511.

16. Titulaer MJ, McCracken L, Gabilondo I, et al. Treatment and prognostic factors for long-term outcome in patients with anti-NMDA receptor encephalitis: an observational cohort study. Lancet Neurol 2013; 12: 157-165.

17. Dalmau J, Lancaster E, Martinez-Hernandez E, et al. Clinical experience and laboratory investigations in patients with anti-NMDAR encephalitis. Lancet Neurol 2011; 10: 63-74.

18. Ruggles KH, Haessly SM, Berg RL. Prospective study of seizures in the elderly in the Marshfield Epidemiologic Study Area (MESA). Epilepsia 2001; 42: 1594-1599. 